JURNFL

INOVRSI EKRNOMI

\section{The influence of leader-member exchange and organizational climate on military organizational commitment}

Adya Hermawati ${ }^{1}$, Hartini Prasetyaning Pawestri ${ }^{2}$, Kartika Dewi Sri Susilowati ${ }^{3}$, Martaleni ${ }^{4}$, Roby Sambung 5

Master of Management Department, Postgraduate Program, Universitas Widyagama Malang, Indonesia ${ }^{1}$ Accounting Department, Faculty of Economics and Business, Universitas Widyagama Malang, Indonesia ${ }^{2}$ Management Accounting Department, Politeknik Negeri Malang, Indonesia ${ }^{3}$ Management Department, Faculty of Economics and Business, Universitas Gajayana Malang, Indonesia ${ }^{4}$ Management Department, Faculty of Economics and Business, Universitas Palangka Raya, Indonesia ${ }^{5}$

Received: 27-09-2021। Revision: 16-10-2021 | Accepted: 21-10-2021

DOI: https://doi.org/10.22219/jiko.v6i03.18276

\begin{abstract}
This study aims to determine the effect of leader-member exchange and organizational climate on organizational commitment mediated by work performance. This study is explanatory research, and the sample analysis of this research is the military personnel of the 30th maintenance department, Abdul Rachman Saleh Malang Airbase. In this study, the researchers set a sample size of 100 respondents and tested the research's model by the Partial Least Square approach. This study shows that organizational climate can directly encourage organizational commitment while leader-member exchange has a positive effect when mediated by work performance.
\end{abstract}

Keywords: Leader-member exchange; organizational climate; organizational commitment; work performance

\footnotetext{
${ }^{1}$ hermawatiadya @gmail.com
} 


\section{Introduction}

Every organization that is established has the hope of developing, continuing to exist, and achieving its goals according to the vision and mission that has been set. The existence of human resources as the leading resource of the organization plays a vital role in making this happen. Human resources provide energy, thoughts, talents, creativity, and efforts to the organization (Hermawati, 2019). The role of HR in organizations can be seen from two things, namely: 1) work effort, which is reflected in the quality of the effort given by a person or group within a specific time, and 2) being able to work to produce individual and organizational work achievements.

Work performance is a record of the results obtained through certain job functions or activities for a certain period (Budiningsih, 2017). A person achieves a work result in carrying out the tasks assigned to him based on skills, experience, sincerity, and time (Marasi, 2019). In achieving work performance, several influencing factors can trigger whether the work performance of the organization's HR is high or low. At least, there are 3 (three) factors that affect work performance, namely: 1) individual factors, 2) psychological factors, and 3) organizational factors (Jurfrizen, 2018).

Depohar 30th Abdul Rachman Saleh Air Base Malang is the implementing unit for the Air Force Material Maintenance Command (Koharmatau) which has the task of carrying out maintenance of the heavy level of fixed-wing aircraft, turbine motors, component maintenance, material inspection, calibration of Precision Measuring Instruments (AUP) and material production or limited fabrication and Field Maintenance Assistance (Banharlap). Depohar 30 in carrying out its duties is supported by three maintenance implementing units: Maintenance Units (Sathar) 31, 32, and 33.

Based on the evaluation results of Commander Depohar 30, the performance or work performance of all Maintenance Units (Sathar) still needs to be improved for the future at an optimal level, based on the concept of work performance as an achievement of results or degree of accomplishment, whereas far as which the organization can achieve its work performance by predetermined goals. Information about the results of the organization's work achievements is then used as an evaluation material, and "follow-up" steps in determining policies and decisions related to the work processes carried out by the organization so far (Hermawati, 2020).

Many factors influence individual attitudes towards the organization, one of which is a commitment to the organization. Commitment is an attitude that reflects the extent to which an individual knows and is bound to his organization (Hardjo, 2018). As Mulyana said, employees who have organizational commitment would continue to survive and then be involved in efforts to fight for the organization's vision, mission, and goals. Hence, it is 
appropriate that every organization hopes to achieve a competitive advantage by supporting employee commitment to its organization (Mulyana, 2017).

Employees who feel more committed to the organization have reliable habits, plan to stay longer, and devote more effort to work (Hermawati, 2017). Attention to employee commitment to the organization is an absolute must because it will impact their work performance. Organizations should pay attention to high employee commitment to the organization (Murdiyani, 2019). This is intended to detect early workers who are less than optimal so that things do not happen that can harm the organization.

Leaders must consider the quality of the relationship with employees, which can be judged from the level of closeness of the relationship and interaction between leaders (superiors) and subordinates. In organizational behavior, especially the theory governing the relationship between leaders and subordinates, it is popularly termed Leader-Member Exchange (LMX); Atmaja (2020) mentions that LMX theory describes the role of making a relationship process between a leader and subordinates, and this exchange relationship is developed over time. LMX can be caused by differences in attitudes received from subordinates from their superiors; these differences can be formed based on likes and dislikes, differences in competence, trust, and several other reasons owned by superiors (Sukoco, 2020).

In addition to the LMX theory, another phenomenon related to the problem of the non-optimal performance of Depohar 30 personnel related to work environment factors is the organizational climate. Organizational climate can be interpreted as patterns of behavior, attitudes and feelings that are displayed repeatedly which are used as characteristics of organizational life (Nasution, 2017). According to Sugeng (2017) organizational climate greatly affects employee performance, namely by creating a healthy organizational climate within the organization. Thus, employees will be more enthusiastic and are expected to improve employee performance.

In addition, general studies on organizational climate and commitment take samples of private companies or civil servants. Therefore, this study expands the literature on the characteristics of private employees, civil servants, and soldiers. The rest of this paper is a method, empirical result, and conclusion.

\section{Method}

This type of research is explanatory research, which is data analysis using quantitative methods. This research aims to determine the effect of LMX and organizational climate on organizational commitment mediated by work performance. The sample analysis of this research is the military personnel of the 30th Maintenance Depot Abdul Rachman Saleh Malang Airbase. In this 
study, the researchers set sample size of 100 respondents because they were already representative. The data examiner uses the Partial Least Square approach, a powerful analytical method that is not based on many assumptions. As a comparison, we also conducted semi-structured interviews with commanders of 30th Maintenance Depot Abdul Rachman Saleh Malang Airbase.

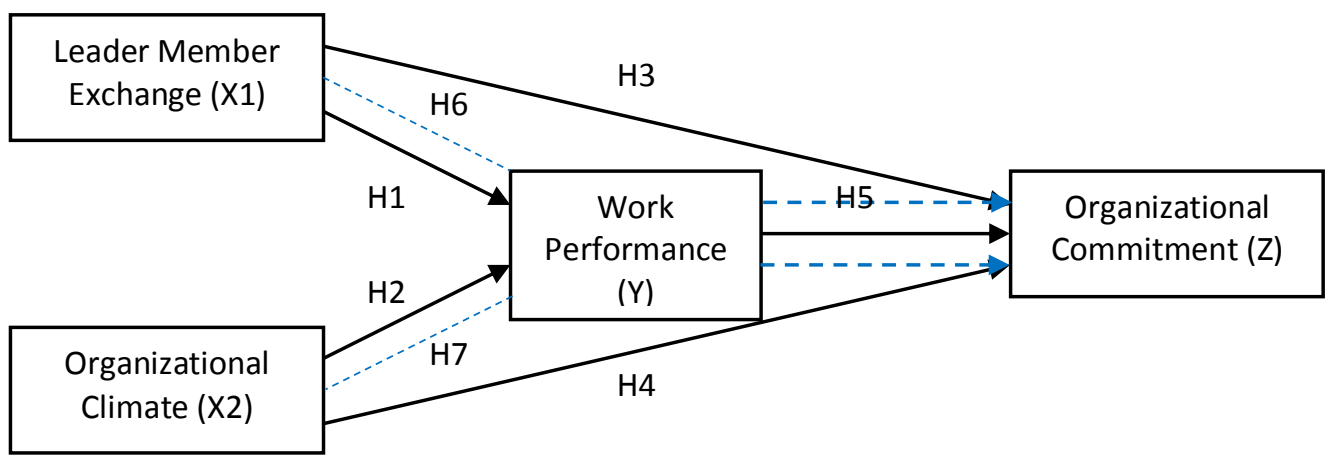

Figure 1. Research Framework

\section{Empirical Result}

The test of the structural model (inner model) can be seen from the R-Square value for each endogenous variable as the predictive power of the structural model. Changes in the value of R-Square can be used to explain the effect of certain exogenous latent variables on endogenous latent variables. Based on the test results using the SmartPLS program, the following results were obtained in Table 1.

In Table 1, it can be seen that the R-Square value of the endogenous latent variable of Work Performance (Y) obtained is 0.789 or $78.9 \%$. These results show that Leader-Member Exchange (X1) and Organizational Climate (X2) together have an influence of $76.9 \%$ on Work Performance (Y). In comparison, $21.1 \%$ is the remaining enormous contribution of influence given by other factors not studied.

Furthermore, the endogenous latent variable Organizational Commitment $(\mathrm{Z})$ obtained is 0.733 ; these results show that the Leader-Member Exchange (X1), Organizational Climate (X2), and Work Performance (Y) together have an effect of $73.3 \%$ on Organizational Commitment $(Z)$. In comparison, the remaining $26.7 \%$ is a significant contribution of influence given by other factors not examined.

In addition to R-Square, structural model testing (inner model) can also be seen from the Q-Square value. The Q-Square value has the same meaning as the coefficient determination (R-Square) in regression analysis, where the higher the Q-Square, the model can be said to be better or more fit with the data. The results of the calculation of the Q-Square value is 0.943. Q-Square 
value shows that the diversity of the research data that the research model can explain is $94.3 \%$. At the same time, the remaining $5.7 \%$ is explained by other factors that are outside the research model. Thus, this research model can be declared to have the worthy goodness of fit from these results.

Table 1. Result of path analysis

\begin{tabular}{|c|c|c|c|}
\hline Path & $\begin{array}{c}\text { Original } \\
\text { Sample }\end{array}$ & $\begin{array}{c}t- \\
\text { Statistics }\end{array}$ & $\begin{array}{c}p- \\
\text { Values }\end{array}$ \\
\hline $\begin{array}{l}\text { Leader-Member Exchange }(\mathrm{X} 1) \rightarrow \text { Work } \\
\text { Performance }(Y)\end{array}$ & 0.356 & 3.892 & 0.000 \\
\hline Iklim Organisasi $(\mathrm{X} 2) \rightarrow$ Work Performance $(\mathrm{Y})$ & 0.560 & 5.769 & 0.000 \\
\hline $\begin{array}{l}\text { Leader-Member Exchange }(\mathrm{X} 1) \rightarrow \text { Organizational } \\
\text { Commitment }(\mathrm{Z})\end{array}$ & 0.055 & 0.455 & 0.649 \\
\hline $\begin{array}{l}\text { Iklim Organisasi }(X 2) \rightarrow \text { Organizational } \\
\text { Commitment }(\mathrm{Z})\end{array}$ & 0.309 & 3.860 & 0.000 \\
\hline $\begin{array}{l}\text { Work Performance }(\mathrm{Y}) \rightarrow \text { Organizational } \\
\text { Commitment }(\mathrm{Z})\end{array}$ & 0.523 & 3.314 & 0.001 \\
\hline $\begin{array}{l}\text { Leader-Member Exchange }(\mathrm{X} 1) \rightarrow \text { Work Performance } \\
(\mathrm{Y}) \rightarrow \text { Organizational Commitment }(\mathrm{Z})\end{array}$ & 0.187 & 2.342 & 0.020 \\
\hline $\begin{array}{l}\text { Iklim Organisasi }(\mathrm{X} 2) \rightarrow \text { Work Performance }(\mathrm{Y}) \rightarrow \\
\text { Organizational Commitment }(\mathrm{Z})\end{array}$ & 0.293 & 3.137 & 0.002 \\
\hline R-square & \multicolumn{2}{|c|}{0.789} & \\
\hline Q-Square & \multicolumn{2}{|c|}{0.943} & \\
\hline
\end{tabular}

The Commander of the 30th Maintenance Depot, Abdul Rachman Saleh Malang Airbase, places great emphasis on the superior-subordinate relationship as a critical approach in mobilizing personnel in carrying out the tasks/works that are their responsibilities and obligations. Furthermore, the results achieved are expected to optimize the performance of both. In this case, the Commander builds a different reciprocal relationship with the existing personnel at the enlisted, non-commissioned, and officer levels. The method used by the Commander in working, namely by carrying out various managerial functions, ranging from planning, organizing, driving, and task and people-oriented supervision. The Commander is well aware that the leader cannot achieve these managerial tasks alone, but by mobilizing the people, he leads. The creation of good quality superior and subordinate relationships can influence perceptions, attitudes, and behavior, both superiors and subordinates who have this relationship.

The organizational climate created in 30th Maintenance Depot Abdul Rachman Saleh Malang Air Base involves all aspects of the social environment. All personnel deeply feel it in carrying out their jobs that are their responsibilities and obligations. A conducive organizational climate has 
encouraged personnel involvement so that they can work and complete their duties optimally, safely, and comfortably. By being engaged, personnel is expected to commit, desire to contribute, and have a sense of being involved in the work. The organizational climate created in 30th Maintenance Depot Abdul Rachman Saleh Malang Air Base able to encourage the improvement of personnel performance as indicated by a productive work appearance, the provision of adequate organizational technology and working conditions (such as offices and other facilities), then mutually supportive communication flows in terms of quantity and quality, in line with decision-making practices at all levels. On the other hand, the welfare of personnel is well considered.

\section{Conclusions}

This study concludes that leader-member exchange can improve the work performance; the better organizational climate can increase the work performance of personnel; leader-member exchange is not able to increase organizational commitment; the better organizational climate can increase organizational commitment; better work performance can increase organizational commitment; leader-member exchange and organizational climate can increase organizational commitment mediated by work performance.

These findings indicate that organizational climate is the dominant factor in encouraging soldiers' commitment. Therefore, policies related to human resources must focus on aspects of organizational climate. In addition, this study also shows that work performance can mediate leader-member exchange to impact organizational commitment positively. Thus, performance-based appreciation for holistic achievement measurement can also be implemented to encourage organizational commitment.

\section{References}

Atmaja, G. S., Suharnomo, S., \& Perdhana, M. S. (2020). Pengaruh Leader-Member Exchange (Lmx), Kualitas Lingkungan Kerja (Quality of Work Life) terhadap Budaya Organisasi dan Dampaknya terhadap Kinerja Pegawai (Studi Pada PT Bank Pembangunan Daerah Jawa Tengah Cabang Utama Semarang) (Doctoral dissertation, UNDIP: Fakultas Ekonomika Dan Bisnis).

Budiningsih, S., Warso, M. M., \& Yulianeu, Y. (2017). Hubungan Pengembangan Karir dan Kompensasi Terhadap Kepuasan Kerja dan Implikasinya Pada Komitmen Organisasional PT. Pertani (Persero), Wilayah Jateng \& DIY. Journal of Management, 3(3).

Hardjo, S. (2018). Hubungan Persepsi Iklim Organisasi dan Interaksi Atasan Bawahan (Leader Member Exchange) dengan Organizational Citizenship 
Behavior pada Pegawai Perguruan Panca Budi Medan. Jurnal Psychomutiara, 1(1), 40-50.

Hermawati, A., \& Mas, N. (2017). Mediation effect of quality of worklife, job involvement, and organizational citizenship behavior in relationship between transglobal leadership to employee performance. International Journal of Law and Management.

Hermawati, A., \& Puji, R. (2019). The transglobal leadership-based strategy of MSMEs performance optimization of Malang Raya and the implementation of quality of work life. Research Journal of Textile and Apparel.

Hermawati, A. (2020). Transglobal leadership approach to sustainable tourism competitiveness at tourism sector-engaged MSMEs through integrated human resource performance and responsible marketing. International Journal of Tourism Cities.

Jufrizen, J. (2018). Pengaruh Kompensasi dan Pengembangan Karir Terhadap Komitmen Organisasi Dengan Kepuasan Kerja Sebagai Variabel Intervening Pada PT. Perkebunan Nusantara III (Persero) Medan. Jurnal Ilmiah Manajemen Dan Bisnis, 15(1).

Mulyana, A., \& Sugiharto, M. D. (2017). Pengaruh Kepemimpinan Dan Sistem Penghargaan Terhadap Kepuasan Kerja Serta Implikasinya Terhadap Komitmen Organisasional Karyawan PT Bank BJB Syariah.

Murdiyani, Y. (2019). Pengaruh leader member exchange, iklim organisasi, dan keselamatan kesehatan kerja ( $k 3$ ) terhadap loyalitas karyawan pada pt bumi mas perdana semarang (Doctoral dissertation, UMK).

Nasution, M. I. (2017). Pengaruh Stres Kerja, Kepuasan Kerja Dan Komitmen Organisasi Terhadap Turnover Intention Medical Representative. MIX: Jurnal Ilmiah Manajemen, 7(3), 224238.

Sugeng, A., \& Amboningtyas, D. (2017). Pengaruh Gaya Kepemimpinan Transformasional, Karakteristik Individu dan Karakteristik Pekerjaan terhadap Kepuasan Kerja Karyawan Serta Implikasinya terhadap Komitmen Organisasi Di CV. Gema Insan Mandiri Semarang. Journal of Management, 3(3).

Sukoco, W., Lubis, M. R., \& Hasanuddin, H. (2020). Hubungan Leader Member Exchange dan Kepuasan Kerja dengan Komitmen Organisasi pada Tenaga Pendidik Sekolah Polisi Negara Kepolisian Daerah Sumatera Utara. Tabularasa: Jurnal Ilmiah Magister Psikologi, 2(2), 168-181. 
